\title{
Intercultural Communication Competence Developed by Chinese in Communicating With Malays in Bangka Island, Indonesia*
}

\author{
Deddy Mulyana \\ Padjadjaran University, Bandung, Indonesia
}

\author{
Agustina Zubair \\ University of Mercu Buana, Jakarta, Indonesia
}

\begin{abstract}
This study aims to explore the cultural identity of Chinese related to their self-perception, their perception of Malays, and their communication with the Malays in Bangka Island, Indonesia, emphasizing the Chinese intercultural communication competence in terms of their self-presentation in business relationships with the Malays. The study employed an interpretive approach, more specifically the symbolic interactionist and dramaturgical tradition. The researchers focused on intercultural communication experiences and competence as enacted by the 25 Chinese in the area of the research. The study used in-depth interviews with the Chinese as the main method with some observation of the Chinese communication with the Malays. The researchers also interviewed eight Malays as additional subjects of the research to corroborate the research findings. The study found that the Chinese in Bangka Island perceived themselves as open and willing to mingle with the Malays. They are hospitable, hardworking, tenacious, frugal, and fond of maintaining long-term relationships. In contrast, in the Chinese view, the Malays are open and willing to mingle with others, obedient to the teachings of Islam, but they are lazy and are keen on being flattered, consumptive, and easily seduced. In terms of their intercultural communication competence, the Chinese are skillful in their self-presentation by employing various verbal and nonverbal tactics to adjust themselves to the interpersonal, group, and business situations where they encounter the Malays in their everyday lives.
\end{abstract}

Keywords: Chinese, Malays, Bangka Island, self-perception, intercultural communication competence, tactics of self-presentation

\section{Introduction}

Despite the fact that Chinese have lived in an archipelago now called Indonesia for centuries, few studies have focused on their communication with other racial and ethnic groups, including the dominant society consisting of various ethnic groups in the country such as the Malays, the Javanese, the Sundanese, the Bataknese, the Minangkabaunese, etc.. Even rarer are studies using interpretive approaches, such as phenomenology,

\footnotetext{
${ }^{*}$ A much shorter and very different version of this paper is written in the Indonesian language by Agustina Zubair in Ijad, Vol. 3 , no. 1 (2013), Journal of the Postgraduate Program, Universitas Padjadjaran, Indonesia, based on her research under the guidance/supervision of Deddy Mulyana.

Acknowledgements: We would like to thank Peter Morse and Carolyn Calloway-Thomas for their comments on earlier drafts of this research paper.

Deddy Mulyana, professor, Ph.D., Faculty of Communication Science, Padjadjaran University, Bandung, Indonesia.

Agustina Zubair, lecturer, Ph.D., Faculty of Communication Science, University of Mercu Buana, Jakarta, Indonesia.
} 
symbolic interactionism, dramaturgical analysis, ethnomethodology, etc.. Previous research on the Chinese in Indonesia has mainly focused on their history, acculturation, and integration into the Indonesian society, for example the work of Suryadinata (1997) and Usman (2009), their political thinking (Suryadinata, 2005), their contribution to social development such as education, health, and journalism (Ang, 2009), and their folklore (Danandjaja, 2007).

Of a few interpretive studies dealing with Chinese communication with non-Chinese in Indonesia, Herawati (2005) explored the roles of nuclear family in socialization among the Chinese society in Pontianak, West Kalimantan. Herawati found that the nuclear family played an important role in socializing Chinese cultural values among their children so that the children adhered to these values and had deep understanding of the Chinese culture. She also found that the majority of the informants had a positive attitude toward the Chinese culture and considered non-Chinese culture to be inferior.

A few years later, Handoko (2009) investigated communication between Chinese and Malays in Palembang, South Sumatera, in the business context. He found that the Chinese in Palembang often used three verbal codes: the official Indonesian language, the Palembang Malay language, and the Chinese language, depending on their communication partner. For example, the Chinese used the Palembang Malay when they spoke to the local Palembang people, used the Indonesian language when they spoke to non-Palembang people and non-Chinese people, but they used Chinese language or at least some Chinese words or phrases mixed with the local Malay or the Indonesian language when they spoke to their Chinese fellows. They often switched these verbal codes from one code to another in the same situation as long as people from different ethnic groups were around them, for example when they dealt with their customers from different ethnic groups in their shops.

Some studies of Chinese communication with non-Chinese in Indonesia have employed an objective-quantitative perspective, such as Lestari (2006) who investigated the implication of interethnic stereotypes in intercultural business communication among Javanese, Balinese, and Chinese who were engaged in the silver business in Yogyakarta. She indicated that their intercultural communication competence was molded by motivation, knowledge, and skills as formulated by Spitzberg (2012). She also found that intercultural ethnocentrism among the business people under investigation had declined due to the globalization of business, the awareness of other ethnic groups, and the development of communication technology supporting their intercultural adjustment.

An interesting aspect of the Chinese people's long existence in many parts of Indonesia is their style of communication, both verbal and nonverbal, with the dominant society where they live. In Indonesia, this consists of communication with diverse ethnic groups who live in various islands, such as the Javanese in Central Java and East Java, the Sundanese in West Java, or the Malays in Sumatera, Bangka, and Belitung, the Banjarese in Kalimantan, and the Bugis-Macassarese in Sulawesi. In Bangka Island where a significant number of Chinese have lived for generations, Chinese behaving like the Malays is commonplace, such as using the Malay language, adhering to Malay customs, wearing Malay attire, and socializing with Malays. Yet, the Chinese and the Malays are two separate communities characterized by mutual stereotyping. There has not been research into the Chinese people's communication with the Malays prior to this present one and, as far as the authors are aware, this research into the Chinese in Bangka Island is the first of its kind.

The authors assume that due to their long historical relationships with the Malays, the Chinese in Bangka 
Island have gained a sort of intercultural communication competence based on their knowledge of the local culture (which includes language, etiquette, food, traditional and religious ceremonies, etc.) and their real experiences in associating with the Malays in everyday activities. According to Spitzberg (2012), communication competence refers to "social behavior that is appropriate and effective for a given context" which incorporates motivation, communication knowledge and skills. For the Chinese in Bangka Island, this communication competence is useful in their daily economic transactions with the Malays. A Chinese in Bangka Island knows with whom he or she communicates, where and when he or she communicates, and what is the likely response of his or her communication partner. With this communication competence, the Chinese in Bangka Island know how to win their business transactions which give them profit and enable them to survive on the island.

Most of the Chinese in Bangka Island, as in other islands in Indonesia, are business people, just like their forebears in their home country. Chinese business in Indonesia has been carried on for centuries, since the first generations came to the archipelago in Southeast Asia now called Indonesia. In developing their business, the Chinese have encountered not only other Chinese but also non-Chinese composed of hundreds of ethnic groups in Indonesia such as the Malays, the Javanese, the Sundanese, the Balinese, the Bataknese, the Minangkabaunese, the Bangkanese, the Banjarese, the Bugisnese, the Manadonese, and others.

\section{Research Objectives}

This study aims to delineate the self-perception of the Chinese in Bangka Island, part of the Bangka-Belitung Province of Indonesia, their perception of the Malays with whom they often communicate, and to explore the intercultural communication competence of the Chinese in dealing with the Malays in the business context. The study will show that the main intercultural communication competence of the Chinese constitutes the basis for their ability to adjust themselves into the Malay culture, more specifically their verbal language and nonverbal behavior to impress Malays and to achieve their economic ends. The study will demonstrate how the Chinese employ verbal and nonverbal tactics of impression management in the course of their intercultural communication with the Malays in Bangka Island. The authors argue that the Chinese in Bangka Island are competent in their intercultural business communication with the Malays, based on their knowledge of the Malay language and the traits of the Malays, although this does not necessarily mean that the Chinese always manipulate or even cheat their Malays business partners or clients.

\section{Theoretical Framework}

It cannot be denied that in today's world, to succeed in business, one must master intercultural business communication which incorporates some understanding of his or her business partner's culture, including verbal language and nonverbal communication styles (see Varner \& Beamer, 2005; Lewis, 2006; Hofstede, Hofstede, \& Minkov, 2010). Culture is omnipresent and affects the way people communicate in all contexts of life. The success of business people partly depends on how they comprehend the culture of their business partners or clients, including their verbal language, the nonverbal behavior, and their cultural values. Some scholars have associated the knowledge and skills of intercultural communication with intercultural communication competence.

Although some scholars have tested intercultural communication competence empirically, such as Lestari (2006), in various settings and have related it with other variables, the authors are more interested to find out 
inductively how people are competent in this aspect. Thus, this study is based on the theoretical perspectives of George Herbert Mead (1934), Erving Goffman (1955, 1959), and Stella Ting-Toomey (1985). Each of these theories complements each other and should be seen as a unity. While some of Mead's theory of self (symbolic interaction) has been extended by Goffman (Littlejohn \& Foss, 2009), Goffman's concept of facework (1955) and theory of self-presentation (1959) has inspired Ting-Toomey's $(1985,1988)$ face negotiation theory (see Littlejohn \& Foss, 2009).

According to symbolic interactionism, communication does not involve two or more people who behave in a series of simple causal chains in which they give automatic response. Rather, communication must be understood “as a dynamic, evolving process of mutual coordination and role taking" (Littlejohn \& Foss, 2009, p. 946). In this process, the actors assume identities and play roles based on these identities. They are involved in the dynamic process of indicating to one another who and what they are. In such situations, they typify each other and define the situations they encounter, and are engaged in the action based on this context of social identities and the definition of situation. Self-presentation, as Goffman (1959) indicated, aims to produce definitions of the situation and social identities for the actors and these influence what kinds of interactions are appropriate and inappropriate for the actors in the immediate situation.

In the contexts of the Chinese in Bangka Island, based on the meanings the Chinese attribute to the Malays' actions, the Chinese may change their own actions to fit in with the Malays' actions. This modification of behavior requires the Chinese to determine in advance what meanings, motives, or intentions exist behind the actions of the Malays. Such a process will only be possible if the Chinese possess and share some cultural experiences, especially Malay language. The Chinese respond not simply to the action of the Malays but, rather, to the meanings, motives, and intentions of that action. Consequently, understanding, regardless of whether it is convenient or inconvenient, will be achieved if the Chinese and the Malays attribute the same meanings to those verbal and nonverbal symbols.

There is a possibility that the Chinese engage impression management merely to please the Malays, in order to pursue their economic goals. The process of being Chinese, in this regard, is fluid and changes as required to fit social situations. To show loyalty to their Malay business partners or clients, the Chinese will demonstrate that they are less Chinese and are more like Malays. However, as members of their own ethnic group, they may show strong allegiances to and in their ethnic group, if necessary, belittling or even ridiculing the Malays in the latter's absence.

Borrowing Lyman and Douglass' ideas (1973), the effort of the Chinese in Bangka Island to utilize some means of impression management purports to reduce stereotypes that the Malays have toward them, stimulating the Malays' sympathy for their status as a minority, and inducing the Malays to have a more favorable attitude toward them. Thus, strategies and tactics of impression management enacted by the Chinese in Bangka Island as a minority group in their communication with the Malays may vary, even including endeavors to demonstrate ethnic identities and behaviors acceptable to the Malays.

Since the Chinese in Bangka Island act in accordance with their interpretation of the Malays' action and the immediate situation, it is possible to explore tactics by which the Chinese manipulate their ethnic identities, their verbal language, and nonverbal behavior, including their facial expression, and the motives behind such expression management, although there are limits in this ethnic manipulation, at least due to their physical constraints such as the appearance of their eyelids and skin color which are difficult to manipulate. Proper facial expressions must be maintained by the Chinese in Bangka Island so that the Malays cannot detect their true feelings, especially negative 
ones, so that the Malays have favorable attitude toward them. This face-saving is commonplace among collectivistic ethnic members such as the Chinese and the Malays in Bangka Island to cultivate social harmony.

\section{Research Questions}

As there is a possibility that ethnic identity is manipulated for personal and economic gain, this research also takes account of certain situations in which the Chinese in Bangka Island may define themselves differently from the way they normally do. Thus, this research also explores how the Chinese select certain alternative behaviors when they communicate with the Malays, particularly in face-to-face business situations, based on their definition of the situation, regardless of whether they choose to role play or employ genuinely expressed behavior.

When viewing ethnicity as a form of communication within the Chinese community and between the Chinese and the Malays, two relevant questions can be raised:

(1) How do the Chinese as the subjects of this study identify themselves as members of a particular ethnic group in Bangka Island dominated by the Malays and how do the Chinese identify with the Malays?

(2) What tactics are used by the Chinese in presenting themselves before the Malays to achieve their personal and economic gains and what are the motives of those tactics of impression management?

\section{Research Method}

This study is part of larger research which lasted approximately nine months. To conduct the whole research the authors were involved in a lot of interaction between the Chinese who worked as business people in Bangka Island. Through a snowball sampling method, the authors interviewed 25 Chinese (15 Chinese in Muntok, seven in Pangkal Pinang, two in Sungai Liat, and one in Jakarta). These Chinese subjects are descendants of the Hakka, Hokkian, and Teu Chu Chinese ethnic groups. In this paper, the authors use pseudonyms to protect the identities of the subjects.

The authors observed the way the Chinese subjects communicated daily with the Malays as their communication partners, especially as customers. The focus of the research was the Chinese verbal language and their nonverbal behaviors when they were communicating with the Malays and when they were communicating with their Chinese fellows. Their comments, as quoted in this study, are translated into English.

In addition to interviewing and observing Chinese subjects, the authors interviewed eight Malays who had wide knowledge of the Chinese culture and had interacted a lot with the Chinese in Bangka Island, including those who had prominent (bureaucratic, political, and professional) positions in the research area. These interviews with the Malays aimed to gain their perception of the Chinese and their confirmation of the Chinese communication with the Malays.

\section{Research Findings}

Based on the authors' research in Bangka Island, the study found that communication between the Chinese and the Malays are omnipresent, although this communication is characterized by latent mutual stereotypes.

\section{Interethnic Perception}

The Chinese perceived themselves as open and hospitable in communicating with the Malays. They are careful in their treatment of Malays to avoid conlicts and to be able to do business with them. They embrace a principle that the Chinese and the Malays in Bangka Island should not upset each other. The Chinese in Bangka 
Island consider themselves to be hardworking, tenacious, frugal, and keen on maintaining long relationships with the Malays. They consider the Malays to be open, fond of associating with other people, obedient to the teachings of Islam, but on the other hand lazy, easily seduced, fond of being flattered and consumptive. In brief, the Chinese tend to look down on the Malays.

The Malays are open, but their sense of struggle power is less than that of the Chinese. They do not want to be in difficulties. The Malays have the habit of saying "Dak kawah susah" ("Don't bother") or "Mane ke nek" ("It is up to you") which expresses apathy. (Myung)

The Malays are fond of being praised. They like exhibiting their money, even if they have got a little profit. They cannot stand seeing a neighbor buy a car. He wants to buy a car too. (Liem)

The Malays like being flattered. For instance, "You are still young, but you already have a nice house and nice things". (Ying)

If the Malays get 10 as the profit, they spend 10. If we get 10, we spend two. (Chang)

On the other hand, in the Malays' perception, the Chinese are hardworking but calculative and even stingy; they use and justify whatever means to achieve their economic ends. According to the Malays, the Chinese are even willing to bribe others to obtain their business goals. The Malays' perception of the Chinese are not necessarily true. However, the Malays' antagonistic view of the Chinese and vice versa, as will be delineated later, merely indicate that ethnic boundaries between the Chinese and the Malays are widespread. Barth's (1969) argument is still relevant that in spite of intensive communication among ethnic groups, markers still remain to differentiate one's own ethnic group from others. These markers do not have to be unique and tangible such as language, food, and artefacts, but they are considered to be special attributes of the ethnic group, whether they be real or imagined, some of which may evolve from their cultural legacy.

The Chinese in Bangka Island used the term Tong Ngin to refer to themselves as the descendants (Ngin) of a favorable, wise, and civilized dynasty (Tong). This self-label constitutes a kind of ethnocentrism to indicate that they are different from and superior to the Malays whom they identify as Fan Ngin which literally means "people (Ngin) who speak sentences with reverse (Fan) structures". For instance, as described by one informant, Myung, for the Chinese, a chicken egg is Kay Cun (Kay is chicken and Cun is egg), so the language structure is the same as English, but the Malays call the chicken egg telur ayam (telur is Cun and ayam is Kay), which becomes Cun Kay in Chinese.

The actual meaning of Fan Ngin as intended by the Chinese in Bangka Island is "the people who do not keep their words", thus belittling or criticizing the Malays although in daily conversations they may explicitly indicate to the Malays that the Malays are equal to them and that the Malays are good people.

The Malays tend not to keep their words. They say yes but what they mean is no. They say insya Allah (if God wills) to mean that they will not come. (Myung)

Sorry to say that the Malays are labeled Fan Ngin by the Chinese. Their life style is not good. When they get the money 1000, they spend 1000 for food, then they work again tomorrow. (Ying)

Many Malays are not aware of the meaning of Fan Ngin intended by the Chinese. The Malays do not really care about what stereotypes the Chinese hold about them in their minds as long as they do not disturb their lives. The Malays as the majority feel that the Chinese know how to interact with the Malays in the way tolerated by the 
Malays. Thus the Malays let the Chinese work in the economic realm and take advantage. The Malays are aware that they are not as steadfast in pursuing economic goals as the Chinese are.

In the fieldwork, the authors found that the intercultural communication competence of the Chinese in dealing with the Malays is based on their ability to display their cultural identity and to adjust themselves to the cultural (Malay) environment where they live. Their intercultural communication competence is based on two modes of self-presentation, that is, the verbal mode and the nonverbal mode, each model consisting of several tactics. They have to display such ability to preserve their self-image and improve it when necessary. These two modes of impression management are both common and are particularly apparent in daily business face-to-face communication with the Malays. Figure 1 shows the tactics of the verbal impression management and those of the nonverbal impression management starting from the most dominant on the left side to the least dominant on the right side.

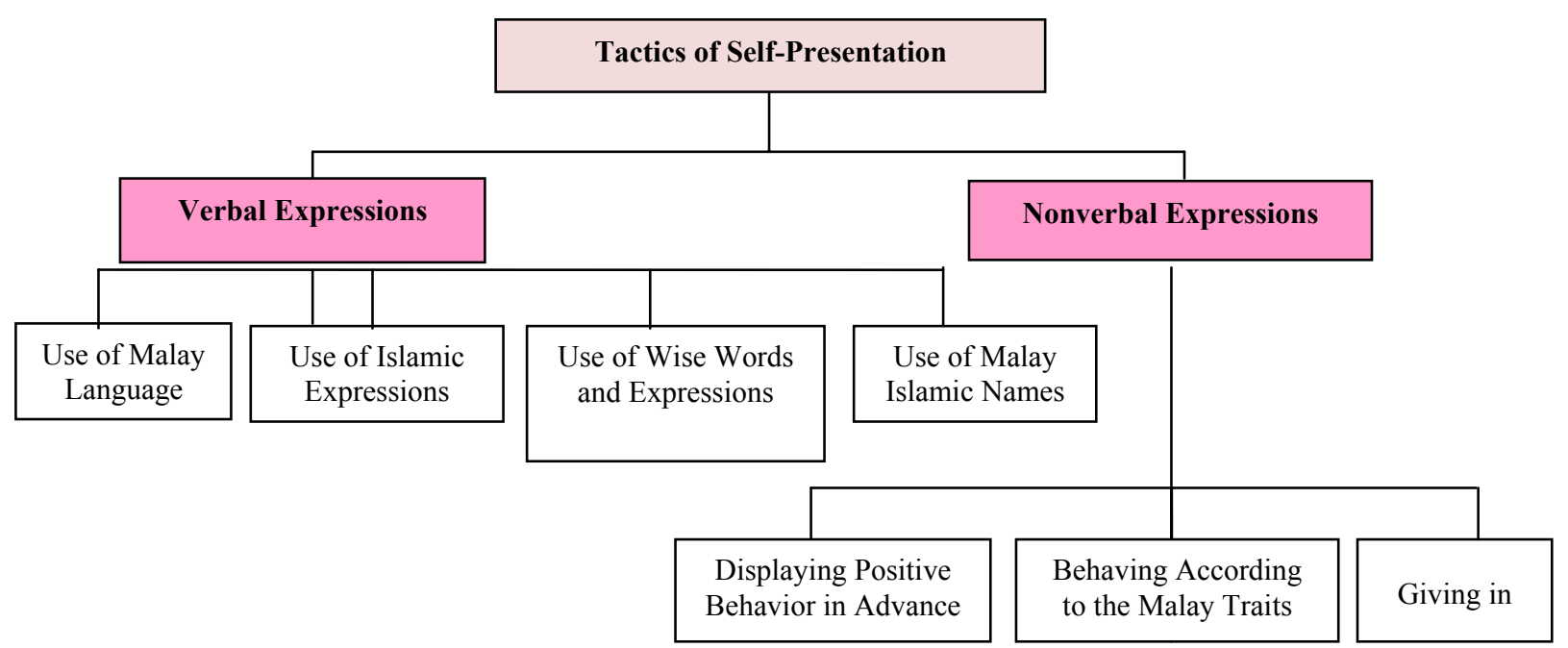

Figure 1. The model of the Chinese self-presentation tactics in communicating with the Malays in Bangka Island, Indonesia.

\section{Verbal Tactics of Impression Management}

The verbal mode of self-presentation include: the use of Malay language, the use of Islamic expressions, the use of wise words or expressions, and the use of Islamic or Malay personal names.

The Chinese in Bangka Island often use the Malay language in their daily encounters with the Malays, and in business encounters, although they use the Chinese language when they communicate with their fellow Chinese in their internal environment and also in public places when they talk with their Chinese fellows. The Chinese master the local Bangkanese Malay, including its accent and dialect. Some of them speak it in such a way as if they have lost their Chinese identity if observers ignore the physical characteristics, especially their eyes and their lighter skin.

When a small group of Chinese and Malays get together, usually they speak the Malay language. In case a Chinese does not comprehend what another Chinese says in Malay, although this incident is rare, he or she may use Chinese words, phrases, or sentences for a while, and then switches back to the Malay language. These research findings on this verbal code switching among the Chinese in Bangka Island is similar to what Handoko (2009) found in his research of the Chinese use of the local language in Palembang. 
The Chinese know that the Malays like being greeted and do not like to be ignored. They also know that the Malays like small talk before discussing serious business matters. So the Chinese almost always greet the Malays and respond to the Malays' greetings. When meeting others, the Malays will make small talk, for example by asking "Nek Kemane?" ("Where are you going?"), “Apa gawe?” ("What are you doing?"), or "Ape cerite?" ("What is the story/news?"). These questions do not always require answers since they are meant to admit the presence of others and at the same time to show kindness to others. These local greetings have become the entry point to enter subsequent conversations because the Malays are well known as people who like chatting.

The second tactic shows that the Chinese are fluent in using some Islamic terms and expressions often used by the Malays, although they are not Muslims, such Assalammualaikum (Peace be upon you) when they meet their Malay counterparts or when they deliver speeches in front of the Malays. When they are asked how they are or when they hear good news from others, they frequently say Alhamdulillah (Praise be to God) as a sign of gratitude and relief. They even utter Insya Allah (if God wills) when they are invited to attend gatherings or when they promise to do something in relation with the Malays. They also often say Bismillah (in the Name of God the Most Beneficent the Most Merciful) prior to doing something before the Malays. They utter all those expressions seriously as if they really believe in Islam and comprehend the deeper meanings of the expressions. Ming, a businessman but also a member of the provincial People's Representatives Assembly, admitted that he says "Assalamualaikum" when encountering a Malay or when he begins his speech. He closes his speech by saying "Wabillahi taufiq walhidayah" (By the guidance of God). He would also say "Waalaikum salam" (Peace be upon you too) in answering a Malay's Islamic greeting.

Third, the Chinese impression management is enacted by expressing wise words, phrases, or sentences praising themselves in their conversations with the Malays to counter the stereotypes that the Malays have toward them. The Bangkanese Malays have stereotypes that the Chinese in Bangka Island are dishonest, stingy, impolite, rude, and use any means to achieve their business goals, even through deceptions. Based on their experiences in interacting with the Malays, the Chinese in Bangka Island are aware of the Malays' unfavorable perception of them. So in their interaction with the Malays, the Chinese strive to wipe out the negative characteristics of the Chinese as attributed by the Malays. For instance, they often say that honesty is very important to them, since without trust, their business will not succeed.

Honesty is like the second soul, yes our second soul. If people do not trust us, it is as if we lose our soul. In Mandarin language: Xien Yong (Trust) Shi (is) Di En (number 2) Sheng Ming (Soul). (Tan)

In their communication with the Malays, the Chinese frequently emphasize the importance of honesty, humility, brotherhood, and similarities between the Chinese and the Malays. For example, they emphasize the teaching of Confucius that all people are brothers and sisters because they live in the same island where the Chinese ancestors came as laborers and where some of them have even married Malays.

According to Confucius, all four oceans are brothers. Arrogance invites loss, but humility brings berkah (good will/advantage). (Ming)

We are all brothers and sisters. We are not different, no matter where we come from. According to Confucius, people in an island surrounded by oceans are brothers and sisters. In the Chinese language: Tsi hai Zhai Nei-Se hai Che Nei. (Tan) 
Based on the assumption that the Chinese and the Malays are equal and should respect each other, the Chinese are self-confident and easy-going in their relationships with the Malays.

Fourth, the Chinese impress the Malays by possessing and using Malay or Islamic names such as Taufik Salim, Halim Susanto, Gunawan, and Frandi Rusmin. In their interaction with the Malays, the Chinese prefer to be addressed by their Islamic or Malay names. However, this does not mean that they abandon their Chinese names. They still cherish their Chinese names (using Chinese characters) and use them in their interaction with their Chinese family members, relatives, and Chinese business fellows.

The use of Islamic or Malay names is especially important on formal occasions in schools or in government offices, particularly when they communicate with government officials in the process of applying for business permits. They are aware that business permits will be granted faster or more easily if they display some personal symbols such as names, attires, or verbal expressions deemed Islamic or nationalistic.

\section{Nonverbal Tactics of Impression Management}

Nonverbal tactics of impression management are related to body language such as body posture and hand gestures, facial expression, head movement, vocal characteristics, silence, and the use of certain cultural ornaments deemed favorable in the eyes of the Malays, and their presence in cultural events. In this context, the Chinese in Bangka Island display three nonverbal tactics of impression management to cultivate favorable impression in the eyes of the Malays.

First, they maintain positive behavior in order to be favorably perceived by the Bangkanese Malays, such as by appearing honest, polite, humble, sociable, patient, hardworking, and trusted, to counter the negative stereotypes the Malays have toward them. This positive behavior is often accompanied by body language and certain gestures, such as a little bow and head nodding to indicate politeness, silence, and even smiles to overcome confusion, embarrassment, or anger.

Smiles or at least a nice face must be shown to the Malays to win their hearts although they are offended by the Malays' statements or actions. Once they offend the Malays, they will likely lose some of their customers which will mean losing financial profit. The Chinese feel that if they are not kind enough to the Malays, they must try again and again to be kind to be accepted by the Malays. In order to please the Malays, the Chinese do not demonstrate their property and possessions in public in an extreme way, or to the degree that the Malays see them as arrogant. By getting along with the Malays, the Chinese have ample time to seek information about prospective Malay business partners or clients which will in turn give them some knowledge on how to deal with them.

The Chinese in Bangka Island believe that if they display a positive attitude, the Malays will also have a positive attitude toward them. This positive attitude is indicated in such a way and to the degree that they are well liked by the Malays. They are convinced that even if the Malays do not show positive behavior toward them after they have shown their own positive behavior for the first time, the Malays will show their positive behavior after they show their positive behavior after the second, the third, the fourth, or the fifth time. This principle refers to their character, that is, steadfastness and unwillingness to give up in their business. If their initial offer is rejected, they will not surrender and they will not be desperate. Rather, they will make efforts until their second offer, the third, the fourth, or even the fifth one, is accepted.

Further exploration of the Chinese interaction with the Malays indicated that some of the Chinese are 
involved in social activities perceived unfavorably by the Malays, such as gambling and drinking alcohol. However, they just do not give out information about those activities in front of the Malays. They keep such activities hidden. They are aware that the Malays who are basically Muslims consider gambling or drinking alcohol to be Islamically unlawful. According to one subject, Chen, to develop their relationships, the Chinese must cultivate a "positive reputation" or the best image they can. For example, they do not tell the Malays that they like gambling or that they like drinking. In fact, Chen occasionally invites his Chinese friends who are older than him to gamble in his house to kill time. One of the researchers saw this informant with his four friends gambling at the back of his house, one of them was known to the researcher as an older brother of her high school friend.

Second, they show their behavior according to the attributes of the Malays. For example, although the Chinese in Bangka Island do not like to be involved in long conversations, because they are more occupied with their business, to please the Malays who are keen on long conversations, they let themselves be engaged in long conversations and drink coffee with the Malays. They praise the Malays in terms of their possessions, their characters, their skills, or their achievements. They know that the Malays like compliments and praises.

To show that they appreciate the Malay tradition, the Chinese also attend Malay ceremonies, some of them being Islamic, such as circumcision ceremonies, visiting the Malays on the Idul Fitri Day (the celebration after the fasting month) or several days after that. During the fasting month the Chinese are not seen eating in public during the day to show tolerance for the religious fasting of the Muslims.

Whether the Malays like us or dislike us, it depends on us. We have to adjust our ways to the Malay ways. (Ming)

Third, the Chinese like giving in. They know that the Malays in Bangka Island hate arrogant people and that the Malays are hot tempered and will be quickly angered. They know it is difficult to keep smiling while they are offended or angry. So the Chinese prefer to be silent to avoid interpersonal frictions, even if the Malays are angry with them, for the security and the continuity of their business is more important to them than everything else.

I have to play my expressions. If I do not like something, I keep smiling. On the other hand, I may like something, but I keep silent. (Chen)

A government official may impose on us regulations that do not fit my logic. But I keep saying "Yes." In practice, these regulations are adjusted to my plan. (Ying)

When Malays are angry, we keep silent and listen to them. They will realize later that they are wrong. When they apologize to us, we forgive them. (Chang)

\section{Conclusion}

In this paper, the authors have indicated how the Chinese as the subjects of the study were competent in their intercultural communication, especially in the business context, with the Malays in Bangka Island in Indonesia. They were creative and demonstrated their high flexibility in their communication with the Malays. The symbolic interactionist theory (Mead, 1934), Goffman's concept of impression management (1959), and Goffman's and Ting-Toomey's concept face or facework (Littlejohn \& Foss, 2009) clearly indicate their benefits in exploring the nature of the Chinese intercultural competence in terms of their communication adaptability and flexibility with Malays in the business context.

The authors argue that the Chinese in Bangka Island in social as well as business contexts are competent in 
their intercultural communication with the Malays, both verbally and nonverbally, in the sense that they are skillful in their impression management before the Malays, although they also face some constraints due to the existing stereotypes the Malays have toward them and due to their immutable physical characteristics as Chinese. However, this does not mean that all their communication with the Malays is insincere all the time, especially in the non-business context. This certainly requires another investigation.

The Chinese have attained their intercultural communication competence based on the knowledge about the Malay culture, specifically the Malay language and Malay customs in Bangka Island. Using Goffman's (1959) perspective, the information the Chinese have about a Malay helps them to define the situation, enabling them to know in advance what they expect from the Malay. Consequently, they know what the best way is to induce the response they expect from the Malay. Their cultural communication competence has contributed to their survival and intercultural adjustment in Bangka Island inhabited by the dominant Malay society and to the continuation of their business.

\section{References}

Ang, Y. G. (2009). Memoar Ang Yan Goan: Tokoh Pers Tionghoa yang Peduli Pembangunan Bangsa Indonesia (The biography of Ang

Yan Goan: A Chinese press prominent figure who cares about Indonesian development). Jakarta: Yayasan Nabil \& Hasta Mitra.

Barth, F. (1969). Ethnic groups and boundaries. London: Allen \& Unwin.

Danandjaja, J. (2007). Folklor Tionghoa (The Chinese folklore). Jakarta: Pustaka Utama Grafiti.

Goffman, E. (1959). The presentation of self in everyday life. Garden City, C.Y.: Double Day.

Handoko, B. (2009). Komunikasi Antarbudaya pada Masyarakat Cina-Melayu Palembang: Studi Komunikasi Kedwibahasaan pada Masyarakat Cina Bisnis-Melayu di Palembang Sumatera Selatan (Intercultural communication between Chinese and Malays in Palembang: A study of bilingual switching between Chinese business people and Malays in Palembang South Sumatera) (Unpublished master's thesis). Postgraduate Program Padjadjaran University, Bandung, Indonesia.

Herawati, N. (2005). Komunikasi Masyarakat Multikultural: Peran Keluarga Inti dalam Proses Sosialisasi pada Masyarakat Cina Pontianak (Communication in multicultural society: The role of families in socialization among Pontianak Chinese) (Unpublished doctoral's thesis). Postgraduate Program Padjadjaran University, Bandung, Indonesia.

Hofstede, G., Hofstede, G. J., \& Minkov, M. (2010). Cultures and organizations: Software of the mind. New York: McGraw-Hill.

Lestari, P. (2006). Implikasi Stereotip Antaretnik terhadap Kompetensi Komunikasi Bisnis Antarbudaya: Studi di Kalangan Pengusaha Perak Jawa, Bali, dan Cina (The implication of interethnic stereotypes on intercultural business communication competence: A study of Javanese, Balinese, and Chinese in silver business) (Unpublished doctoral's thesis). Postgraduate Program Padjadjaran University, Bandung, Indonesia.

Lewis, R. (2006). When cultures collide: Leading across cultures (3rd ed.). Boston: Nicholas Brealey International.

Littlejohn, S. W., \& Foss, K. A. (Eds.). (2009). Encyclopedia of communication theory. Los Angeles: Sage.

Lyman, S. M., \& Douglass, W. A. (1973). Ethnicity: Strategies of collective and individual impression management. Social Research, 40(2), 345-365.

Mead, G. H. (1934). Mind, self and society: From a standpoint of a social behaviorist. C. M. Morris (Ed.). Chicago: The University of Chicago Press.

Spitzberg, B. H. (2012). Axioms for a theory of intercultural communication competence. In L. A. Samovar, R. E. Porter, \& E. R. McDaniel (Eds.), Intercultural communication: A reader (13th ed., pp. 424-435). Australia and others (International Edition): Wadsworth.

Suryadinata, L. (1997). The culture of the Chinese minority in Indonesia. Singapore: Times Academic Press.

Suryadinata, L. (Ed.) (2005). Pemikiran Politik Etnis Tionghoa Indonesia 1900-2002 (Political ideas of Indonesian Chinese 1900-2002). Jakarta: LP3ES.

Usman, A. R. (2009). Etnis Cina Perantauan di Aceh (The sojourning Chinese in Aceh). Jakarta: Yayasan Obor, Indonesia.

Varner, I., \& Beamer, L. (2005). Intercultural communication in the global workplace (3rd ed.). Boston: McGraw Hill.

Zubair, A. (2013). Kompetensi Komunikasi Antarbudaya Etnik Cina Bangka (The intercultural communication competence of Chinese in Bangka). Ijad, 3(1), 1-5. 